\title{
SELECTIVITY OF HERBICIDES APPLIED SEPARATELY OR IN COMBINATION IN THE POST EMERGENCE OF RR2 MAIZE
}

\author{
Bruno Flaibam Giovanelli ${ }^{1}$, André Felipe Moreira Silva ${ }^{1}$, Alfredo Junior Paiola Albrecht ${ }^{2}$, Luiz \\ Henrique Freguglia Aiello ${ }^{1}$, Giovani Apolari Ghirardello ${ }^{1}$, Leandro Paiola Albrecht ${ }^{2}$, Ricardo Victoria \\ Filho $^{1}$ \\ 1Universidade de São Paulo - Escola Superior de Agricultura “Luiz de Queiroz”. E-mail: bfgiovanelli@yahoo.com.br;
afmoreirasilva @ hotmail.com; luizaiello@yahoo.com.br; giovani.ghiralelo@ usp.br; rvictori@ usp.br
${ }^{2}$ Universidade Federal do Paraná - Setor Palotina. E-mail: ajpalbrecht@yahoo.com.br; lpalbrecht@ yahoo.com.br
}

\section{ABSTRACT}

The goal of this work was to evaluate the tolerance of maize hybrids $2 \mathrm{~B} 810 \mathrm{PW}$ and $30 \mathrm{~F} 35 \mathrm{HR}$ to herbicides applied alone and in combination. Tests were carried out in the field in a randomized block design with four replicates. The treatments were three herbicides, alone or in combination, in addition to

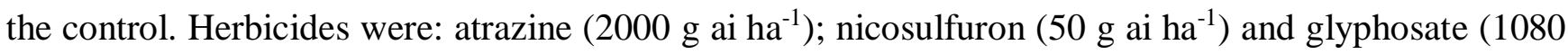
$\mathrm{g}$ ai ha-1). Crop injury was evaluated at 7, 14, 21, and 28 days after application as well as the SPAD index, height, ear height, stem diameter, 1000-grain weight, and yield. In general, the variables were not affected by the treatments. Hybrids 2B810 PW and 30F35 HR showed tolerance to the application in post-emergence (V4) of the herbicides used.

Keywords: Crop injury, Roundup Ready ${ }^{\circledR}, \operatorname{Proof}^{\circledR}, \operatorname{Sanson}^{\circledR}$, Zea mays

\section{SELETIVIDADE DE HERBICIDAS, ISOLADOS OU EM ASSOCIAÇÃO, APLICADOS EM PÓS-EMERGÊNCIA DE MILHO RR2}

\section{RESUMO}

O objetivo do trabalho foi avaliar a tolerância dos híbridos de milho 2B810 PW e 30F35 HR, submetidos à aplicação de herbicidas isolados e associados. Os ensaios foram realizados no campo, e o delineamento adotado foi de blocos casualizados, com quatro repetições. Os tratamentos constituíram-se de três herbicidas, isolados como em associação, além da testemunha. Os herbicidas foram: atrazine (2000 g i. a. ha $\left.{ }^{-1}\right)$; nicosulfuron $\left(50 \mathrm{~g}\right.$ i. a. ha $\left.\mathrm{h}^{-1}\right)$ e glyphosate $\left(1080 \mathrm{~g}\right.$ e. a. ha $\left.{ }^{-1}\right)$. Foi avaliada 


\section{SELECTIVITY OF HERBICIDES APPLIED SEPARATELY OR IN COMBINATION IN THE POST EMERGENCE OF RR2 MAIZE}

fitointoxicação aos 7, 14, 21 e 28 dias após a aplicação e também índice SPAD, altura, altura de inserção da espiga, diâmetro do colmo, massa de mil grãos e produtividade. Em geral, as variáveis não foram afetadas pelos tratamentos. Os híbridos 2B810 PW e 30F35 HR apresentaram-se tolerantes, para a aplicação em pós-emergência (V4) dos herbicidas utilizados.

Palavras-chave: Fitotoxicidade, Roundup Ready ${ }^{\circledR}, \operatorname{Proof}^{\circledR}, \operatorname{Sanson}^{\circledR}$, Zea mays

\section{INTRODUCTION}

Maize crop (Zea mays L.), due to its productive potential, chemical composition and nutritive value, is one of the most important cereals grown and consumed on the planet (FANCELLI \& DOURADO NETO, 2000). Production for the 2015/16 growing season, both in the first and second harvests, was around 83 million tons, compared to 84 million tons in the previous year (CONAB, 2015).

For high yields, it is necessary adequate control of weeds, since their presence interferes in crop growth, development and productivity, which can lead to yield losses of 13 to 88\% (PITELLI et al., 2002). It is essential to perform weed control during the initial phase of development, because in that moment they are more sensitive to the action of herbicides (KNEZEVIC et al., 1994).

Chemical control is the most used method for weed management in maize crop. The recurrent use of certain herbicides or mechanisms of action in the same area has led to the selection of populations resistant to certain chemical groups and consequent control failures (OLIVEIRA JÚNIOR et al.., 2011).

In order to reduce this problem, a tactic to be adopted is Integrated Weed Management (MIPD), which involves various managements, such as crop rotation, and the use of herbicides with different mechanisms of action (VICTORIA FILHO, 2008).

In this context, Roundup Ready2 (RR2) maize has the characteristic of tolerance to the herbicide glyphosate, and with this it has been increasingly used as a tactic for the control of many weeds that compete with maize. This technology is widely used in countries such as the United States, Canada, Argentina, South Africa, Russia, China, among others (MONSANTO, 2012). In Brazil, it has been commercially grown for a few years, which demonstrates the need for research.

Although it is a good control strategy, the application of glyphosate only in post-emergence of maize is not totally safe. Due to its sequential use in maize and other crops, biotypes resistant to this herbicide were selected in Brazil, such as buva (Conyza sp.), sourgrass (Digitaria insularis), ryegrass 
(Lolium multiflorum), windmill grass (Chloris elata), goosegrass (Eleusine indica), and Palmer amaranth (Amaranthus palmeri) (HEAP, 2016).

Thus, the application of herbicide combinations may be an excellent integrated management strategy. The association of glyphosate with other herbicides is effective in weed management. However, associations can affect the full development and even yield of maize RR, because due to the different compositions of the products, there may be synergistic relationships that result in crop injury to the crop. The purpose of this work was to evaluate the tolerance of maize hybrids $2 \mathrm{~B} 810 \mathrm{PW}$ and $30 \mathrm{~F} 35 \mathrm{HR}$ subjected to the application of herbicides alone and in combination.

\section{MATERIAL AND METHODS}

The experiment was conducted in an experimental area in the city of Piracicaba (Central East Region of the state of São Paulo, Brazil), in the 2013/14 and 2014/15 growing seasons.

The soil of the region is classified as Ultisol Ustic Dystrophic Typic (SOIL SURVEY STAFF, 2010) and the site presents an average altitude of 536m. The climate is characterized as Cwa by the climatic classification of Köppen, that is, humid subtropical with drought in the winter. Figures 1 and 2 show data of rainfall and temperature throughout the experimental period for the 2013/14 and 2014/15 harvests.

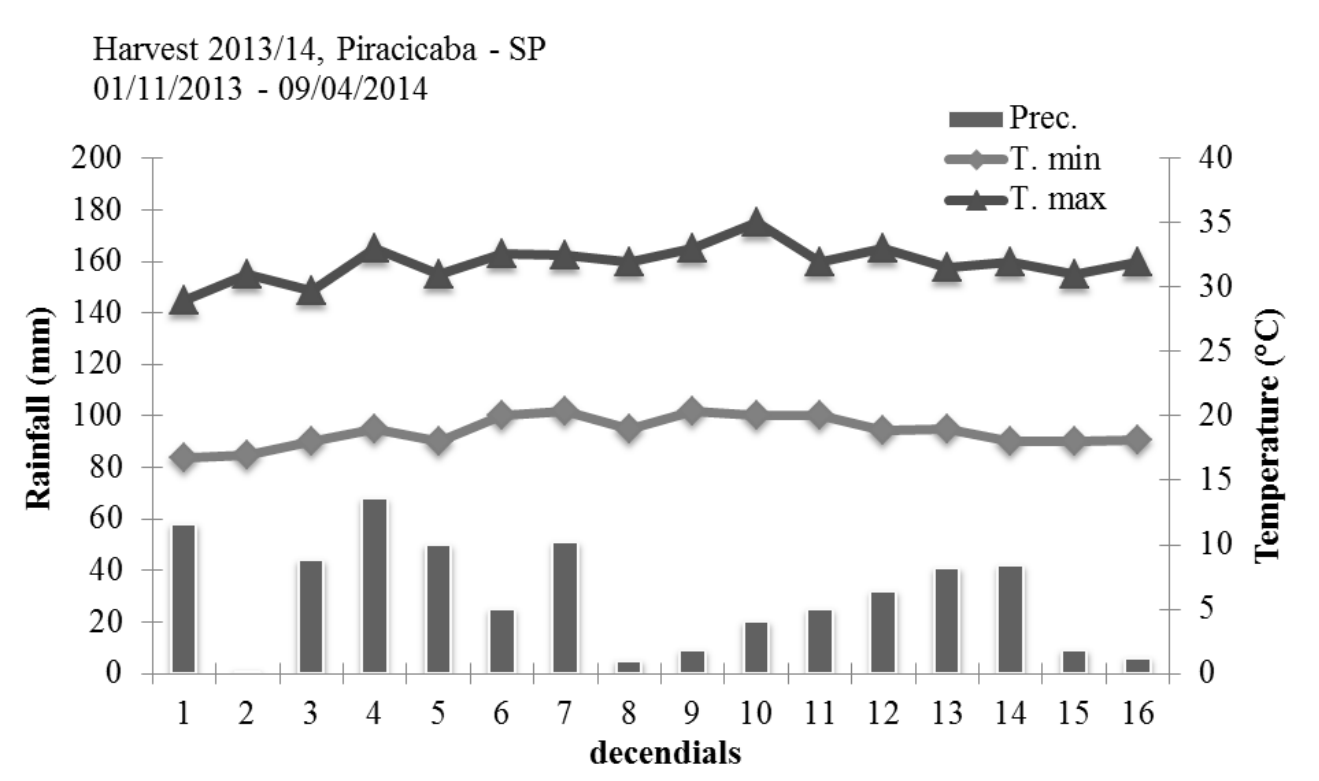

Figure 1. Representation of precipitation, average minimum and average maximum temperatures for the period relative to maize crop cycle, in Piracicaba city, harvest 2013/14. Source: LEB USP/ESALQ 


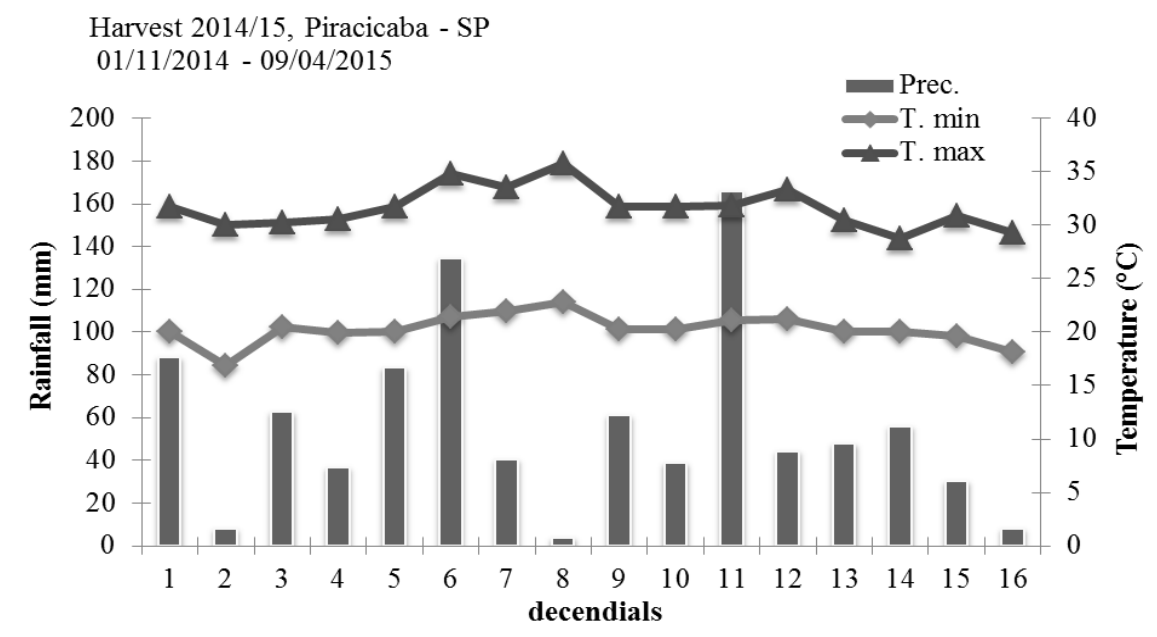

Figure 2. Representation of precipitation, average minimum and average maximum temperatures for the period relative to maize crop cycle, in Piracicaba city, harvest 2014/15. Source: LEB USP/ESALQ

Fertilization practices, crop planting and phytosanitary management were carried out according to the recommendations of Embrapa (2012), and all plots were kept free of weed interference, through manual weeding and hoeing. Table 1 presents chemical and physical soil analysis of the experimental area.

Table 1. Result of soil chemical analysis in the experimental area at 0-20 cm depth. Piracicaba, state of São Paulo.

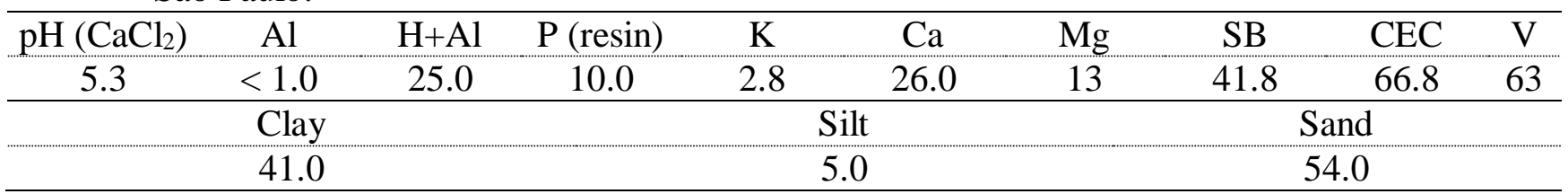

Units: $\mathrm{Al}, \mathrm{H}+\mathrm{Al}, \mathrm{K}, \mathrm{Ca}, \mathrm{Mg}, \mathrm{SB}$ and $\mathrm{CEC}\left(\mathrm{mmol}_{\mathrm{c}} \mathrm{dm}^{-3}\right) ; \mathrm{P}(\mathrm{resin})\left(\mathrm{mg} \mathrm{dm}^{-3}\right) ; \mathrm{V}$, clay, silt, sand (\%).

In the 2013/14 growing season, the experiment was performed with the simple hybrid 2B810 PW, normal cycle, high productive potential and grain production purpose (DOW AGROSCIENCES, 2016). In the $2014 / 15$ crop, the simple hybrid used was the 30F35HR, which has early cycle, adapted to almost all regions of the country, except in the southern region (PIONEER SEMENTES, 2016). 
The experiment was conducted in a randomized block design, with eight treatments and four replicates (Table 2). The application of the treatments was carried out about 20 days after seedling emergence, when the crop was at the V4 stage, that is, with four fully expanded leaves. For the application, a $\mathrm{CO}_{2}$ pressurized backpack sprayer was used at a constant pressure of 2 Bar, flow rate of $0.65 \mathrm{~L} \mathrm{~min}^{-1}$, working $50 \mathrm{~cm}$ from the target, at a rate of $1 \mathrm{~m} . \mathrm{s}^{-1}$, reaching an applied strip of $50 \mathrm{~cm}$ width per nozzle, and providing a spray volume of $200 \mathrm{~L} \mathrm{ha}^{-1}$. The applications, both in the first and second growing seasons, occurred in December. With relative humidity of $60.3 \%$, temperature of $25^{\circ} \mathrm{C}$, and wind speed of $2 \mathrm{~km} \mathrm{~h}^{-1}$, for $2013 / 14$ and relative humidity of $60.5 \%$, temperature of $24^{\circ} \mathrm{C}$, and wind speed of $2 \mathrm{~km} \mathrm{~h}^{-1}$.

Table 2. Herbicides applied alone and in combination in RR2 maize. Piracicaba, state of São Paulo.

\begin{tabular}{|c|c|c|}
\hline Treatments & Commercial Product & Rates (g a.i. ha' $)^{*}$ \\
\hline 1. control & - & - \\
\hline 2. glyphosate & Roundup Ready ${ }^{\circledR}$ & 1080 \\
\hline 3. atrazine & Proof $^{\circledR}$ & 2000 \\
\hline 4. nicosulfuron & Sanson $^{\circledR}$ & 50 \\
\hline 5. glyphosate + atrazine & Roundup Ready ${ }^{\circledR}+$ Proof $^{\circledR}$ & $1080+2000$ \\
\hline 6. glyphosate + nicosulfuron & Roundup Ready ${ }^{\circledR}+$ Sanson ${ }^{\circledR}$ & $1080+50$ \\
\hline 7. atrazine + nicosulfuron & Proof $^{\circledR}+$ Sanson $^{\circledR}$ & $2000+50$ \\
\hline 8. glyphosate + atrazine + nicosulfuron & Roundup Ready ${ }^{\circledR}+$ Proof $^{\circledR}+$ Sanson $^{\circledR}$ & $1080+2000+50$ \\
\hline
\end{tabular}

The experimental units consisted of plots of five meters in length and four rows of maize spaced $0.8 \mathrm{~m}$ apart, and the working area was composed of the two central rows, disregarding half a meter at each end of the plot.

Crop injury was evaluated by means of visual evaluations (from 0, for absence of injuries to $100 \%$, for plant death), considering, in this case, symptoms significantly visible in plants, according to their development (SBCPD, 1995). This evaluation was performed at 7, 14, 21, and 28 days after application (DAA).

SPAD (Soil Plant Analysis Development) index was also evaluated, using the SPAD-502 portable meter, Minolta. This instrument quantitatively evaluates the intensity of the leaf green through the measurement of light transmissions at $650 \mathrm{~nm}$, where light absorption occurs by the chlorophyll molecule and at $940 \mathrm{~nm}$, where no absorption occurs. With these two values, the equipment calculates an SPAD number or index that is normally highly correlated with the chlorophyll content of the leaf (MARKWELL 
et al.., 1995). The SPAD index was measured along with the crop injury evaluations, considering the middle portion of the third fully expanded leaf, evaluating eight plants per plot. However, this measure was only carried out in the second growing season.

The set of variables related to the agronomic performance of the crop was: stem diameter, ear height, total plant height, yield, and 1000-grain weight. These data were collected after the physiological maturity of the crop (R6), when the grains were moist at the harvest point, and the harvest occurred in the working area of the plots.

For the variables stem diameter, total plant height (from the ground surface to the insertion of the male inflorescence - tassel), insertion height (from the ground surface to the ear insertion), we evaluated eight plants per plot. The first one was measured with a caliper, measuring the stem $(10.0 \mathrm{~cm}$ above the ground), with results expressed in millimeters. And the heights were measured with a millimeter ruler of wood, and the results were expressed in centimeters. In order to estimate the yield, ears of the working area of each plot were harvested manually and threshed in an experimental thresher, cleaned with sieves and stored in paper bags. Grains produced in each plot had their mass measured and the moisture corrected to $13 \%$, from these data, the yield was calculated. For the 1000-grain mass, the mass of two sub-samples were determined per plot and the moisture corrected to $13 \%$.

Data obtained were tested by analysis of variance and the necessary breakdowns were performed at $5 \%$ probability. Subsequently, the Tukey’s test was used to compare means $(\mathrm{p} \leq 0.05)$ (PIMENTEL-GOMES \& GARCIA, 2002).

\section{RESULTS AND DISCUSSION}

No differences were detected for the variables total height, ear height and stem diameter, which were not influenced by the post-emergence application of the herbicides used, in the 2013/14 growing season (Table 3).

The 1000-grain mass and yield were not affected by the post-emergence application of the herbicides as compared to the control (Table 4). Osório et al. (2015) found no negative effect in postemergence application of glyphosate (1440 g a.e. ha $\left.{ }^{-1}\right)$, single and sequential management, and

glyphosate $\left(1440 \mathrm{~g}\right.$ a.e. $\left.\mathrm{ha}^{-1}\right)+$ atrazine $\left(1500 \mathrm{~g}\right.$ a. i. ha $\left.{ }^{-1}\right)$, for plant height, ear height and yield in the hybrid 2B587 PW. 
It should be noted that a crop injury evaluation was performed at 7, 14, 21, and 28 DAA. However, no percentage scores were recorded, since the maize plants did not present any visual symptoms of crop injury, results in accordance with those observed for other variables.

The data were registered for the 2014/15 growing season (Tables 5 to 7 ). Crop injury symptoms were observed to a large extent at 14 (DAA), but at 28, these injuries were not verified. The treatments that showed higher percentages of initial crop injury were: atrazine + nicosulfuron and glyphosate + atrazine + nicosulfuron (Table 5).

Table 3. Total height $(\mathrm{m})$, ear height $(\mathrm{m})$, stem diameter $(\mathrm{mm})$ of $2 \mathrm{~B} 810 \mathrm{PW}$ maize plants. Piracicaba, state of São Paulo, 2013/14 harvest.

\begin{tabular}{|c|c|c|c|c|}
\hline Treatments & Rate $\left(\mathrm{g} \text { a.i. } \text { ha }^{-1}\right)^{(1)}$ & $\mathrm{TH}^{*}$ & $\mathrm{EH}^{*}$ & $\mathrm{SD}^{*}$ \\
\hline 1. control & - & 1.67 & 0.74 & 21.66 \\
\hline 2. glyphosate & 1080 & 1.70 & 0.67 & 21.05 \\
\hline 3. atrazine & 2000 & 1.67 & 0.68 & 20.80 \\
\hline 4. nicosulfuron & 50 & 1.62 & 0.67 & 20.51 \\
\hline 5. glyphosate + atrazine & $1080+2000$ & 1.68 & 0.64 & 21.26 \\
\hline 6. glyphosate + nicosulfuron & $1080+50$ & 1.61 & 0.68 & 20.79 \\
\hline 7. atrazine + nicosulfuron & $2000+50$ & 1.59 & 0.67 & 22.07 \\
\hline \multirow[t]{3}{*}{ 8. glyphosate + atrazine + nicosulfuron } & $1080+2000+50$ & 1.64 & 0.67 & 20.54 \\
\hline & Mean & 1.65 & 0.78 & 21.08 \\
\hline & V.C. $(\%)$ & 3.96 & 6.74 & 6.35 \\
\hline
\end{tabular}

TH (total height), EH (ear height) and SD (stem diameter) of maize plants.

${ }^{1}$ Rates in grams of acid equivalent, for the herbicide glyphosate.

*Means are not significantly different by Tukey's test at $5 \%$ probability.

Table 4. Yield $\left(\mathrm{kg} \mathrm{ha}^{-1}\right)$ and 1000-grain mass (g) of 2B810 PW maize. Piracicaba, state of São Paulo, 2013/14 harvest.

\begin{tabular}{|c|c|c|c|}
\hline Treatments & Rate $\left(\text { g a. i. ha }{ }^{-1}\right)^{(1)}$ & Yield** & $\mathrm{GM}^{(2) *}$ \\
\hline 1. control & - & 8797.18 & 240.38 \\
\hline 2. glyphosate & 1080 & 7936.86 & 237.23 \\
\hline 3. atrazine & 2000 & 7140.33 & 272.57 \\
\hline 4. nicosulfuron & 50 & 8509.50 & 236.09 \\
\hline 5. glyphosate + atrazine & $1080+2000$ & 9688.70 & 244.68 \\
\hline 6. glyphosate + nicosulfuron & $1080+50$ & 9350.82 & 239.68 \\
\hline 7. atrazine + nicosulfuron & $2000+50$ & 8430.80 & 221.79 \\
\hline \multirow[t]{3}{*}{ 8. glyphosate + atrazine + nicosulfuron } & $1080+2000+50$ & 8542.07 & 225.10 \\
\hline & Mean & 8549.53 & 236.01 \\
\hline & V.C. $(\%)$ & 10.94 & 5.70 \\
\hline
\end{tabular}

${ }^{1}$ Rates in grams of acid equivalent, for the herbicide glyphosate. ${ }^{2} \mathrm{GM}$ (1000-grain mass) of maize plants.

*Means are not significantly different by Tukey's test at $5 \%$ probability.

**Means in the same column followed by different letters are significantly different by Tukey's test at $5 \%$ probability. 


\section{SELECTIVITY OF HERBICIDES APPLIED SEPARATELY OR IN COMBINATION IN THE POST EMERGENCE OF RR2 MAIZE}

Hybrids of maize considered tolerant to nicosulfuron may exhibit differential sensitivity, depending on the stage of development of the plant, the environment and the rate used (MORTON \& HARVEY, 1992; GUBBIGA et. al., 1995). Nicolai et al. (2008) evaluated the selectivity of nicosulfuron + atrazine $\left(20 \mathrm{~g}\right.$ a.i. $\mathrm{ha}^{-1}+1.500 \mathrm{~g}$ a.i. $\mathrm{ha}^{-1}$ ) for nine maize hybrids (DKB 499, DKB 330, DKB 789, DKB 390, AG 2060, AG 7000, AG 7010, and AG 8088), with application at V4 growth stage, and verified initial crop injury symptoms in some of these, but without losses in grain production.

Table 5. Crop injury (\%) of 30F35 HR maize plants at 7, 14, 21, and 28 (DAA). Piracicaba, state of São Paulo, 2014/15 harvest.

\begin{tabular}{|c|c|c|c|c|c|}
\hline \multirow[b]{2}{*}{ Treatments } & \multirow{2}{*}{$\begin{array}{c}\text { Rate } \\
\left(\mathrm{g} \text { a.i. } \text { ha }^{-1}\right)^{(1)}\end{array}$} & \multicolumn{4}{|c|}{ Crop injury } \\
\hline & & $7 *$ & $\begin{array}{l}14^{*} \\
(\mathrm{DAA})\end{array}$ & $21 * *$ & $28 * *$ \\
\hline 1. control & - & $0.0 \quad \mathrm{a}$ & 0.0 & 0.0 & 0.0 \\
\hline 2. glyphosate & 1080 & 0.0 & 0.8 & 0.0 & 0.0 \\
\hline 3. atrazine & 2000 & 0.0 & 0.0 & 0.0 & 0.0 \\
\hline 4. nicosulfuron & 50 & 0.0 & 0.8 & 0.0 & 0.0 \\
\hline 5. glyphosate + atrazine & $1080+2000$ & 0.0 & 0.0 & 0.0 & 0.0 \\
\hline 6. glyphosate + nicosulfuron & $1080+50$ & 2.3 & 2.3 & 0.0 & 0.0 \\
\hline 7. atrazine + nicosulfuron & $2000+50$ & 3.5 & 3.0 & 0.0 & 0.0 \\
\hline 8. glyphosate + atrazine + nicosulfuron & $1080+2000+50$ & $3.3 \mathrm{~b}$ & 2.5 & 0.0 & 0.0 \\
\hline & Mean & 1.12 & 1.16 & 0.00 & 0,00 \\
\hline & C.V.(\%) & 21.25 & 30.03 & 0.00 & 0,00 \\
\hline
\end{tabular}

${ }^{1}$ Rates in grams of acid equivalent, for the herbicide glyphosate.

* Means are not significantly different by Tukey's test at $5 \%$ probability.

**Means in the same column followed by different letters are significantly different by Tukey's test at 5\% probability.

According to Albrecht et al. (2014), due to the massive presence of resistant, tolerant or even perennial weeds, and outside the ideal application stage, the farmer applies high rates of glyphosate beyond the recommended rate, mainly due to its greater use plasticity, however, this type of application is erroneous.

The application of high rates of glyphosate, even in RR2 maize, can cause some damage to the crop. In agreement with Krenchinski et al. (2013), it was possible to observe a decline in plant height, due to the increase in glyphosate rates.

In the present study, the post-emergence application (V4) of the herbicides tested did not interfere with the variables of height, stem diameter and SPAD index (Table 6). 
Osório et al. (2015) found no negative effect of the application of glyphosate (1440 $\mathrm{g}$ a.e. ha $\left.{ }^{-1}\right)$, single and sequential management, and glyphosate $\left(1440 \mathrm{~g} \mathrm{e} . \mathrm{a} \cdot \mathrm{ha}^{-1}\right)+$ atrazine $\left(1500 \mathrm{~g}\right.$ i.a. ha $\left.{ }^{-1}\right)$, in postemergence, for the variables height, ear height and SPAD index.

Correia et al. (2013) demonstrated that the treatments containing nicosulfuron differed in grain yield in relation to atrazine applied alone, and control without application, for hybrid DKB390, between stages V4 and V5.

Data of yield and 1000-grain weight showed no significant differences and indicated the tolerance of RR2 maize to the herbicides tested (Table 7). Correia et al. (2013) also found no negative effect of the application of glyphosate (960 g a. e. ha $\left.{ }^{-1}\right)+$ atrazine (1000 g a. i. ha ${ }^{-1}$ ) applied post-emergence in RR2 maize for the 400-grain weight and the yield.

Table 6. Total height $(\mathrm{m})$, ear height $(\mathrm{m})$, stem diameter $(\mathrm{mm})$ and SPAD index of $30 \mathrm{~F} 35 \mathrm{HR}$ maize plants. Piracicaba, state of São Paulo, 2014/15 harvest.

\begin{tabular}{llllll}
\hline Treatments & $\begin{array}{l}\text { Rate } \\
(\mathrm{g} \mathrm{a} \text { i. ha })^{-1}\end{array}$ & $\mathrm{TH}^{*}$ & $\mathrm{EH}^{*}$ & $\mathrm{SD}^{*}$ & $\begin{array}{c}\text { SPAD* } \\
\text { index }\end{array}$ \\
\hline 1. control & - & 2.07 & 1.06 & 18.23 & 57.38 \\
\hline 2. glyphosate & 1080 & 1.99 & 1.05 & 17.88 & 57.80 \\
\hline 3. atrazine & 2000 & 2.06 & 1.04 & 18.45 & 58.73 \\
\hline 4. nicosulfuron & 50 & 2.06 & 1.06 & 18.63 & 58.00 \\
\hline 5. glyphosate + atrazine & $1080+2000$ & 2.08 & 1.08 & 18.10 & 56.20 \\
\hline 6. glyphosate + nicosulfuron & $1080+50$ & 2.02 & 1.04 & 18.63 & 56.60 \\
\hline 7. atrazine + nicosulfuron & $2000+50$ & 1.99 & 1.06 & 18.30 & 55.85 \\
\hline 8. glyphosate + atrazine + nicosulfuron & $1080+2000+50$ & 2.02 & 1.08 & 17.95 & 54.13 \\
\hline & Mean & 2.04 & 1.06 & 18.27 & 56.83 \\
\hline
\end{tabular}

TH (total height), EH (ear height) and SD (stem diameter) of maize plants.

${ }^{1}$ Rates in grams of acid equivalent, for the herbicide glyphosate.

*Means are not significantly different by Tukey's test at $5 \%$ probability.

Table 7. Yield $\left(\mathrm{kg} \mathrm{ha}^{-1}\right)$ and 1000-grain mass (g) of 30F35 HR maize plants. Piracicaba, state of São Paulo, 2014/15 harvest.

\begin{tabular}{|c|c|c|c|}
\hline Treatments & Rate $\left(g \text { a. i. ha }{ }^{-1}\right)^{(1)}$ & Yield** & $\mathrm{GM}^{(2) *}$ \\
\hline 1. control & - & 8647.02 & 353.12 \\
\hline 2. glyphosate & 1080 & 8669.75 & 337.36 \\
\hline 3. atrazine & 2000 & 9016.11 & 360.66 \\
\hline 4. nicosulfuron & 50 & 9677.45 & 358.99 \\
\hline 5. glyphosate + atrazine & $1080+2000$ & 10484.90 & 375.41 \\
\hline 6. glyphosate + nicosulfuron & $1080+50$ & 9180.15 & 368.04 \\
\hline 7. atrazine + nicosulfuron & $2000+50$ & 8947.42 & 371.49 \\
\hline \multirow[t]{3}{*}{ 8. glyphosate + atrazine + nicosulfuron } & $1080+2000+50$ & 9632.91 & 357.12 \\
\hline & Mean & 9281.96 & 360.26 \\
\hline & V.C. $(\%)$ & 10.33 & 7.39 \\
\hline
\end{tabular}

${ }^{1}$ Rates in grams of acid equivalent, for the herbicide glyphosate. ${ }^{2} \mathrm{GM}$ (1000-grain weight) of maize plants.

*Means are not significantly different by Tukey's test at $5 \%$ probability. 


\section{SELECTIVITY OF HERBICIDES APPLIED SEPARATELY OR IN COMBINATION IN THE POST EMERGENCE OF RR2 MAIZE}

The application of herbicide combinations may be an excellent integrated management strategy, as long as these associations do not cause damage to the development of the crop of interest. Thus the results obtained in the present work are important in the positioning of herbicides associated with glyphosate, in the management of weeds in RR2 maize.

\section{CONCLUSION}

In general, the RR2 maize hybrids, 2B810 PW and 30F35HR, were tolerant to the herbicides used applied in post-emergence (V4).

\section{REFERENCES}

ALBRECHT, A.J.P.; ALBRECHT, L.P.; BARROSO, A.A.M.; VICTORIA FILHO, R. 2014. O milho RR2 e o glyphosate: Uma revisão. Revista Brasileira de Herbicidas, Londrina, v.13, n.1, p.58-67

CONAB. 2015. Acompanhamento da safra brasileira: Grãos: Safra 2014/2015, décimo segundo levantamento, Brasília, 134 p.

CORREIA, N. M; SANTOS, E.A. 2013. Teores foliares de macro e micronutrientes em milho tolerante ao glyphosate submetido a herbicidas. Semina: Ciências Agrarias. Londrina, v.34, p.3165-3171

DOW AGROSCIENCES. 2016. Dow Sementes - Catálogo de Híbridos de Milho. Indianapolis. 4p.

EMBRAPA. 2012. Sistema de Produção: Cultivo do Milho. Disponível em: <http://www.cnpms.embrapa.br/publicacoes/milho_8_ed/index.htm> Acesso em: 13 out. 2013.

FANCELLI, A.L.; DOURADO NETO, D. 2000. Ecofisiologia e fenologia. In: Produção de milho, Agropecuária: Guaíba, p.21-54.

GAZZIERO, D.L.P. 2015. Misturas de agrotóxicos em tanque nas propriedades agrícolas do Brasil. Planta Daninha, Viçosa, v.33, n.1, p.83-92.

GUBBIGA, N.G; WORSHAM, A.D.; COBLE, H.D.; LEMONS, R.W. 1995. Effect of nicosulfuron on johnsongrass (Sorghum halepense) control and maize (Zea mays) performance. Weed Technology, Lawrence, v. 9, n.3, p.574-581.

HEAP, I. 2016. International Survey of Herbicide Resistant Weeds. Available at: <http://www.weedscience.org >. Access in: July 16, 2016.

KNEZEVIC, S.Z; WEISE, S.F; SWANTON, C.J. 1994. Interference of redroot pigweed (Amaranthus retroflexus) in maize (Zea mays). Weed Science, Lawrence, v. 42, p. 568-573.

KRENCHINSKI, F.H. et al. 2013. Avaliação dos índices de clorofila em milho RR2 cultivado na safrinha, submetido à aplicações de glyphosate. In: Seminário Nacional de Milho Safrinha, Dourados. Anais... Brasília: Embrapa.

MARKWELL, J.; OSTERMAN, J.C.; MITCHELL, J.L. 1995. Calibration of the Minolta SPAD-502 leaf chlorophyll meter. Photosynthesis Research, Lubbock, v.46, n.3, p.467-472.

MONSANTO. Produtos - Milho Roundup Ready. 2012. Available at: < http://www.monsant o.com.br/sustentabilidade/produto/milho_roundup_ready_2/milho_roundup_ready_2.asp $\geq$. Access in: August 14, 2016.

MORTON, C.A.; HARVEY, R.G. 1992. Sweet maize (Zea mays) hybrid tolerance to nicosulfuron. Weed Technology, Lawrence, v.6, n.1, p.91-96. 
NICOLAI, M.; CARVALHO, S.J.P.; TAROZZO FILHO, H.; FRANCISCO, M.O.; CAMPOS, L.H.F.; CHISTOFFOLETI, P.J. 2008. Tolerância de híbridos de milho aos principais tratamentos herbicidas pós emergentes da cultura do milho. In: Congresso Brasileiro da Ciência das Plantas Daninhas, 26, Ouro Preto, Anais... Londrina: SBCPD.

INOUE, M.H.; OLIVEIRA JÚNIOR, R.S. 2011. Biologia e manejo de plantas daninhas. In: In: OLIVEIRA JÚNIOR, R. S.; CONSTANTIN, J.; INOUE, M. H. (ed.). Biologia e Manejo de Plantas Daninhas. Curitiba: Omnipax, p.193-215.

OLIVEIRA JÚNIOR, R. S. 2011. Mecanismos de Ação dos Herbicidas. In: OLIVEIRA JÚNIOR, R. S.; COnStAntin, J.; INOUE, M. H.; (ed.). Biologia e Manejo de Plantas Daninhas. Curitiba: Omnipax, p.141-192.

OSÓRIO, C.R.W.S.; BARDIVIESSO, D.M.; SOUZA, E.I.S.; LEITE, R.S.; LEAL, A.J.F.; SOUZA, H.M. 2015. Milho RR submetido a diferentes manejos de herbicidas e adubação foliar. Nativa, Sinop, v.3, n.2, p.78-82.

PIMENTEL-GOMES, F.; GARCIA, C.H. 2002. Estatística aplicada a experimentos agronômicos e florestais: exposição com exemplos e orientações para uso de aplicativos. Piracicaba, Fealq, 309p.

PIONEER SEMENTES. 2016. Híbridos de Milho - 30F35HR. Available at:〈http://www.pioneersementes.com.br/milho/central-de-produtos/produtos/30f35hr $>$. Access in: June 15, 2016.

PITELLI, R.A.; GRAVENA, R.; MEROTTO JR, A.; BARROS, A.C.; PURISSIMO, C.; ZAGONEL, J.; VICENTE, D.; DALBOSCO, M.; KENEBEL, J.; SCHUM, K. 2002. Controle da interferência das plantas daninhas na cultura do milho (Zea mays) com herbicidas aplicados em diferentes épocas. In: Congresso Brasileiro da Ciência das Plantas Daninhas, 23, Gramado. Anais... Londrina: SBCPD.

SBCPD - Sociedade brasileira da ciência das plantas daninhas. 1995. Procedimentos para instalação, avaliação e analise de experimentos com herbicidas. Londrina, SBCPD, 42p.

SOIL SURVEY STAFF. 2010. Keys to Soil Taxonomy. 10 ed., Washington, DC, USDA Natural Resources Conservation Service.

VICTORIA FILHO, R. 2008. Estratégias de manejo de plantas daninhas. In: ZAMBOLIM et al. (ed.). O que Engenheiros Agrônomos devem saber para orientar o uso de produtos fitossanitários. UFV: Viçosa, p.397-464. 